Wang,T.,Liu, J.,C., \& Li,T. (2019). Design Variables for Self-Directed Learning in MOOC Environment. Journal of Educational Technology Development and Exchange, 12(1), 59-78

\title{
Design Variables for Self-Directed Learning in MOOC Environment
}

\author{
Tai Wang \\ Central China Normal University \\ Juhong Christie Liu \\ James Madison University \\ Tonggui Li \\ Peking University
}

\begin{abstract}
Massive Open Online Courses (MOOCs) can meet education needs from diverse social, cultural, and access backgrounds and require a minimal cost of resources from learners. To successfully scaffold large and distributed populations to learn effectively in these MOOCs, the design needs to optimize self-directed learning. In this paper, the researchers investigated the design variables for MOOCs' learning environment that allowed learning choices made by learners. With this study, the researchers developed a 21-item questionnaire based on a review of the literature and their MOOC design and implementation practices, Massive Online Open Course Learning Environment Design Questionnaire (MOOC-LED). The researchers used the quantitative survey study and developed an initial examination of the MOOC-LED factor structure, validity, and internal reliability. The analyses were based on the anonymous data of 162 participants' perception of learning in MOOCs. The scholarly significance of the 21-item MOOC-LED questionnaire is discussed with its limitations, implications, and future directions.
\end{abstract}

Keywords: design variables, MOOCs, self-directed learning, learning choices

\section{Introduction}

Massive Open Online Courses (MOOCs) hold the promise of providing open access to education which would otherwise be impossible for learners with diverse social, economic, and cultural backgrounds (Bonk, Lee, Reeves, \& Reynolds, 2015). However, studies also have demonstrated the needs of the instructional design of MOOCs to scaffold self-directed learning (Handoko, Gronseth, McNeil, Bonk, \& Robin, 2019; Shapiro et al, 2017).

For example, xMOOCs are usually facilitated by teachers, are centralized, and 
follow a cognitive-behaviorist pedagogical approach (Anders, 2015). Many xMOOCs adopt a linear and procedurally paced pedagogical model where learning progress is monitored by teachers. When teachers take charge of moderating the learning pace, the learners may find themselves making passive progress and not having sufficient opportunities to express their needs of adjustment, especially when there is no direct and instant channel of communication in an online environment. On the other end of the MOOC spectrum, cMOOCs (connectivist MOOCs) are based on connectivism, selforganized learning, and networking (Anders, 2015). They are non-linear learning spaces, loosely structured, and not monitored with teacher presence. Although cMOOCs may optimize networked knowledge co-building, they are also intimidating to those who are not used to loosely-structured contexts that require self-directedness (Agonács \& Matos, 2017b).

To combine the merits of both ends while eliminating their drawbacks, a new type of MOOC design framework was proposed by Agonács and Matos (2017b), that is, heutagogy-based MOOC (hMOOC). The hMOOC proposes a design framework for an inclusive MOOC learning environment, not only for learners apt at self-directed learning but also for those with limited experience in self-directed learning. Heutagogy is the study of self-determined learning (Hase, 2009). Built upon andragogy which focuses on adult learners, heutagogy views learners as the major agents in their learning, providing students with a negotiable curriculum and assessment. Consistent with the selfdetermined learning philosophy rooted in heutagogy and closely associated with selfdirected learning and adult education, hMOOC emphasizes the control of learning by learners (Agonács \& Matos, 2017b; Blaschke \& Hase, 2015; Garrison, 1997). Surrounding self- directed learning, Agonács and Matos (2017b) have listed nine dimensions of hMOOC and their correlation to learning effectiveness. For example, when the dimension of collaboration is high, the structure to the learning pathway is low, and then formal learning is less likely to happen. Recently, several research studies have studied these correlations as well (Bonk et al., 2018; Handoko et al., 2019; Shapiro et al., 2017). Further, the results from these studies indicate that the need to study the design factors of MOOCs should be based on students' perception of learning in a selfdirected environment. Therefore, the purpose of this study is to investigate the design factors that can optimize learning choices in a MOOC environment based on learners' perceptions. This paper presents the study about the following two research questions (RQ):

RQ1: What are the design variables for self-directed learning in a MOOC environment?

RQ2: How reliable and valid are these design variables as an instrument to inform MOOC design?

The answers to these questions are expected to help enhance designers' understanding of learners' perceptions of selfdirected learning attributes in MOOCs, and integrate heutagogical strategies in the design of MOOCs.

\section{Literature Review}

\subsection{Design Elements for Distance and Online Learning Environments}

The early design recommendations for distance learning environment were primarily teacher-centered, including teaching styles, learning tasks, and learner-content interactions through teachers' moderation, 
focusing on interactions between teachers and learners (Garrison, Anderson, \& Archer, 1999; Grabowski \& Curtis, 1991; Moore, 1973, 1991). These theories treated distance learning as a joint task led by teachers and fulfilled by students. For example, Grabowski and Curtis (1991) regarded online courses from the hypermedia perspective, in which an online course consisted of three elements: information, instruction as teachers' duty, and learning as learners' duty. Garrison, Anderson, and Archer (1999) regarded online learning as collective behavior of a community. They proposed a community of inquiry model, which contained three elements, including cognitive presence as primarily learners' behavior, social presence as a co-construction by teachers and students, and teaching presence as primarily teachers' behavior. Moore $(1973,1991)$ emphasized the distance between teacher and learner during distant teaching and learning and proposed transactional distance theory. This theory also contained three elements, structure as teachers' duty, dialogue usually initiated and maintained by teachers, and autonomy as learner's duty. Although these early design theories considered teaching and learning elements, they were more geared toward a teacher-centered approach.

As new digital and networked technologies became part of our daily life, teachers were no longer the only source of learning materials anymore. Therefore, it was not inclusive enough to continue to use the traditional teacher-centered framework to view the design elements of a new distance learning environment, especially with large enrollment MOOCs which became very different from the early stages of distance online teaching and learning. Emerging learning theories turned to value more the learning process. For example, Jaggars and $\mathrm{Xu}$ (2016) proposed four online course design elements that were critical to student performance from quality perspective, including organization and presentation, learning objectives and assessment, interpersonal interaction, and use of technology. Merrill (2002) summarized five principles for online course design from the learning cycle perspective, including problem-centered, activation, demonstration, application, and integration.

These design paradigms help designers to recognize factors closely associated with the process of learning. In the meantime, these are goal-oriented or effectiveness-oriented, rather than self-directed learning that allows learning choices. These goal-oriented or effectiveness-oriented design paradigms take learners as their central "object" in design considerations. The assumptions, however, still hold the standpoint that a perfect design can drive learners to accomplish learning tasks. However, with students who have their education or career goals, these types of design can fail to meet learners' needs (Pursel et al., 2016; Shapiro et al., 2017). For example, some learners for career goals may prefer to seek parts of courses (instead of the whole course), which is required at the workplace. And some post-college (e.g., postgraduate) students may prefer to seek a primary or advanced version of a course. In other instances, some adult learners may need personalized learning contracts with MOOC providers. These will need more flexibility that allows more self-directed learning and learning choices, which used not to be considered by none heutagogical designs. The perspectives reviewed about the distance and online learning environment and their design elements are compared and provided in Table 1.

As Table 1 displays, self-directedness in distance and online learning and learning choices are embedded in course design theories and elements proposed in the recent 
Table 1. Distance/Online Course Design Perspective and Elements

\begin{tabular}{|c|c|}
\hline $\begin{array}{c}\text { P e r s p e c tive } \\
\text { (Reference) }\end{array}$ & Elements and Descriptions \\
\hline $\begin{array}{l}\text { community } \\
\text { (Garrison, } \\
\text { Anderson, \& } \\
\text { Archer, 1999) }\end{array}$ & $\begin{array}{l}\text { Cognitive presence: the extent to which learners can construct } \\
\text { meaning through sustained communication. } \\
\text { Social presence: the ability of learners to project their characteristics } \\
\text { into the community. } \\
\text { Teaching presence: to support and enhance social and cognitive } \\
\text { presence to realize educational outcomes. }\end{array}$ \\
\hline $\begin{array}{l}\text { hypermedia } \\
\text { (Grabowski \& } \\
\text { Curtis, 1991) }\end{array}$ & $\begin{array}{l}\text { Information: a flow of messages with many functions. } \\
\text { Instruction: information specifically selected, organized, and sequenced } \\
\text { with deliberate intent that the consumer will remember, apply or act } \\
\text { upon it now or in the future. } \\
\text { Learning: active cognitive processing of information by the consumer. }\end{array}$ \\
\hline $\begin{array}{l}\text { distance (Moore, } \\
\text { 1973, 1991) }\end{array}$ & $\begin{array}{l}\text { Structure: how the teaching program is structured so that it can be } \\
\text { delivered through the various communication media. } \\
\text { Dialogue: the interaction between the teacher and the learner. } \\
\text { Autonomy: the will and ability to exercise powers of learning, to } \\
\text { overcome obstacles for oneself, to try to do difficult learning tasks, and } \\
\text { to resist coercion. }\end{array}$ \\
\hline $\begin{array}{l}\text { leaning cycle } \\
\text { (Merrill, 2002) }\end{array}$ & $\begin{array}{l}\text { Problem-centered: learning is promoted when learners are engaged in } \\
\text { solving real-world problems. } \\
\text { Activation: learning is promoted when existing knowledge is activated } \\
\text { as a foundation for new knowledge. } \\
\text { Demonstration: learning is promoted when new knowledge is } \\
\text { demonstrated to the learner. } \\
\text { Application: learning is promoted when new knowledge is applied by } \\
\text { the learner. } \\
\text { Integration: learning is promoted when new knowledge is integrated } \\
\text { into the learner's world. }\end{array}$ \\
\hline $\begin{array}{l}\text { online learning } \\
\text { assessment } \\
\text { (Jaggars \& Xu, } \\
\text { 2016) }\end{array}$ & $\begin{array}{l}\text { Organization and presentation: ease of navigation and clear organization } \\
\text { of materials. } \\
\text { Learning objectives and assessment: clearly outlining course-level and } \\
\text { unit-level objectives, along with clear expectations for assignments. } \\
\text { Interpersonal interaction: the effectiveness of interpersonal interaction in } \\
\text { reinforcing course content and objectives. } \\
\text { Use of technology: the effectiveness of the chosen technology to support } \\
\text { learning objectives. }\end{array}$ \\
\hline $\begin{array}{l}\text { heutagogical } \\
\text { (Hase, 2009; } \\
\text { Blaschke, 2012) }\end{array}$ & $\begin{array}{l}\text { Learner-centeredness: learner-defined learning contracts, flexible } \\
\text { curriculum, learner-directed questions, flexible and negotiated } \\
\text { assessment. } \\
\text { Reflective practice: learning journals, action research, formative and } \\
\text { summative assessment. } \\
\text { Collaborative learning: team-based, knowledge share. }\end{array}$ \\
\hline
\end{tabular}

* The attributes in bold italicized font are related to self-directedness. 
three decades. These attributes include constructing meaning, projecting personal characteristics in the learning community, active processing of information, performing learning autonomy, learning engagement, and learner-centeredness (Blaschke, 2012; Garrison, Anderson, \& Archer, 1999; Grabowski \& Curtis, 1991; Hase, 2009; Merrill, 2002; Moore, 1973, 1991). However, there are different perspectives and facilitation that would allow learner choices. To illustrate self-directed learning and learning choices in detail, Moore (1973) has made an analogy with dining options:

A child sits expectantly at his mother's table and consumes the meal she places before him. He may try to reject that which he finds unpalatable, or seek extra helpings of what he enjoys, but the nature of the meal is limited and is determined by his mother with little contribution from the child. By comparison, in a cafeteria, in anticipation of the patron's demands, a selection of dishes has been prepared and exposed to view. Those the diner likes he may select; those he dislikes he will certainly reject. His choice may be nutritionally sound, or foolish. He may come in search of a particular fare, which he may find, or, if unsuccessful, he may reject the whole offering, and take his appetite elsewhere (p. 671).

If compared with the child analogy, in a teacher-centered design the learner takes in cognitive information that is only prepared by his/her teacher; while in the cafeteria analogy, the learner's consumption is determined by his own choices. This fits the definition of self-directed learning in adult education, which is "an approach where learners are motivated to assume personal responsibility and collaborative control of the cognitive (self-monitoring) and contextual (self-management) processes in constructing and confirming meaningful and worthwhile learning outcomes" (Garrison, 1997, p. 18). More relevantly, "learner-centeredness is at the heart of heutagogy, and learner agency is a major component of the theory. When engaging in heutagogic practice, the learner takes center stage, as she or he determines the learning path, defining learning objectives and outcomes, as well as selecting how that learning will be assessed. The learning path is non-linear, thus allowing the learner to explore all relevant and available paths to learning" (Blaschke, 2018, p. 130). Therefore, heutagogy seems to meet the needs of a broad spectrum of learning needs (Blaschke, 2018; Hase, 2009).

\subsection{Conceptual Framework Focusing on Learning Choices}

MOOCs have been known for their potential of providing learning opportunities for large populations with low enrollment costs. Factors associated with self-directedness and learning choices seem to play an important role in course completion and the impact of meeting learners' career development and educational needs (Hansen \& Reich, 2015; Pursel et al., 2016). Therefore, relevant literature has been reviewed, with a focus on heutagogy.

Heutagogy is defined as the study of self-determined learning (Blaschke, 2018; Hase, 2009). It indicates that learning occurs when the learner is ready rather than the teacher expects or intends for it to occur. Therefore, heutagogy has a second name: harnessing learning (Hase, 2009). Concerning self-directed learning and learning choices, heutagogy focuses more on learners, while pedagogy focuses more on teachers. Heutagogy studies learner-centered aspects, such as learner as agency that allows learners to negotiate learning objectives with teachers. Heutagogy also extends the concept of learners 
beyond the traditional college age, which seems to fit the MOOC's learning environment (Hansen \& Reich, 2015; Pursel et al., 2016). These lifelong learning needs closely connect with higher-order thinking when making decisions about pursuing education, and investing time and energy in education and career growth (Gregory, Bannister-Tyrrell, Charteris, \& Nye, 2018). To investigate the correlations between higher-order thinking and self-directed learning, Gregory et al. (2018) conducted three case studies. They found that regardless of the postgraduate program structure, samples in each case exhibited a piece of clear evidence on self-adjustment to meet learning needs. Students adapted their beliefs and actions, developed and refined higher-order cognitive processes as required to meet their self-determined learning. Hence, Gregory et al. (2018) suggested that nontraditional students acquire opportunities to question self-beliefs, values, and attitudes that affected critical and higher-order thinking, especially when accessing a variety of MOOC platforms to pursue their program of study.

In response to students' requirements as discussed above, the three design elements derived from heutagogy are learnercenteredness, reflective practice, and collaborative learning (Blaschke, 2012). Learner-centeredness includes learner-defined learning contracts, flexible curriculum, learner-directed questions, and flexible and negotiated assessment. Reflective practice includes learning journals, action research, and formative and summative assessment. Collaborative learning includes team-based learning and knowledge sharing. It is worthy to note that double-loop learning is closely associated with the reflective process of heutagogy (Argyris \& Schon, 1978; Hase, 2009; Tagg, 2010). Heutagogy has been applied with success in different online and offline contexts, "however, never in a massive context" (Agonács \& Matos, 2017a, p. 537). Recently, several studies have revealed the urgency of incorporating self-directed learning and learning choices into MOOC design (Bonk et al., 2018; Handoko et al., 2019; Shapiro et al., 2017). Shapiro et al., (2017) identified factors both inside and outside of the course setting that impacted engagement and learning by investigating why learners took the courses. They interviewed thirty-six participants and found that knowledge, work, convenience, and personal interest were the four most frequent motivation factors. Pursel, et al (2016) also found that students who had already earned bachelor's degrees were significantly more positive about the courses than those with less formal education. They interpreted their study results as that students who earned a bachelor's degree might have better-oriented career motivation and skills to make use of MOOCs as a self-directed online learning environment. However, a survey study completed with 152 MOOC instructors revealed that two-thirds of instructors did not place extensive effort on meeting unique learner needs during course design, and more than two-thirds were not concerned with personalization during course delivery (Bonk et al., 2018). Another recent survey study with 643 students enrolled in MOOCs identified goal setting as one of the unique differences between students who completed their course and those who did not (Handoko et al., 2019). These revealed a close association between the success of personalized learning and the goal setting in learning.

For a large population enrolled in MOOCs, goals can vary widely between learners. These ought to be considered at the design stage so that learners can make proper choices even learning similar content in the same MOOC environment. Therefore, the next improvement measures for MOOC should include more learning choices and the design 
can allow learners' self-directed learning behaviors. These can include learning choices of different phases of learning, progressing through differently perceived difficulties, and access to layered learning resources.

\subsection{Design Elements in Instruments for Online Learning Environment}

A review of existing and relevant instruments for online learning environment design has been conducted. The constructs in these instruments, especially those related to self-directed learning, are extracted and synthesized in Table 2 .

As displayed in Table 2, the construct of interaction is a common factor of design shared by almost all these instruments because of the emphasis on interaction/collaboration in online learning environments. The second and salient construct is related to learnercenteredness, from students' voice, autonomy, control in the learning process, perception

Table 2. Design Elements in Instruments for Online Learning Environment

\begin{tabular}{|l|l|}
\hline \multicolumn{1}{|c|}{ Short Name (Ref.) } & \multicolumn{1}{c|}{ Constructs } \\
\hline $\begin{array}{l}\text { MOLES-S (Thomas, } \\
\text { 2003) }\end{array}$ & $\begin{array}{l}\text { Metacognitive Demands, Student-student Discourse, Student- } \\
\text { teacher Discourse, Student Voice, Distributed Control, } \\
\text { Emotional support, Teacher Encouragement, and Support }\end{array}$ \\
\hline $\begin{array}{l}\text { TROFLEI (Aldridge, } \\
\text { Dorman, \& Fraser, 2004) }\end{array}$ & $\begin{array}{l}\text { Student Cohesiveness, Teacher Support, Equity, } \\
\text { Involvement, Task Orientation, Cooperation, } \\
\text { The investigation, Computer Usage, Differentiation, } \\
\text { Young Adult Ethos }\end{array}$ \\
\hline $\begin{array}{l}\text { DELES (Walker \& Fraser, } \\
\text { 2005) }\end{array}$ & $\begin{array}{l}\text { Personal Relevance, Authentic Learning, Active Learning, } \\
\text { Student Autonomy }\end{array}$ \\
\hline $\begin{array}{l}\text { Mid-Math (Ogbuehi \& } \\
\text { Fraser, 2007) }\end{array}$ & $\begin{array}{l}\text { Personal Relevance, Shared Control, Student Negotiation, } \\
\text { Involvement, Task Orientation, } \\
\text { Normality of Mathematicians, Enjoyment of Mathematics, } \\
\text { Investigation }\end{array}$ \\
\hline $\begin{array}{l}\text { BELS (Wu, Tennyson, \& } \\
\text { Hsia, 2010) }\end{array}$ & $\begin{array}{l}\text { Computer Self-efficacy, Interaction, Learning Climate, System } \\
\text { Functionality, Performance Expectations, Learning Satisfaction, } \\
\text { Content Feature }\end{array}$ \\
\hline $\begin{array}{l}\text { MOOC Criteria(Yousef, } \\
\text { Chatti, Schroeder, \& } \\
\text { Wosnitza, 2014) }\end{array}$ & $\begin{array}{l}\text { Pedagogical Criteria } \\
\text { Assessment } \\
\text { Technical Criteria }\end{array}$ \\
\hline $\begin{array}{l}\text { ADECUR \& UNE } \\
\text { Fernandez, Silvera, \& } \\
\text { Meneses, 2015) }\end{array}$ & $\begin{array}{l}\text { Recognition of Training for Employability, Learning } \\
\text { Methodology, Levels of Accessibility, } \\
\text { Virtual Classroom Environment/Climate }\end{array}$ \\
\hline $\begin{array}{l}\text { 225-Item CEQ } \\
\text { Liu, John, \& Bishop } \\
\text { Courtier, 2017) }\end{array}$ & $\begin{array}{l}\text { Good Teaching, Generic Skills, Clear Goals and Standards, } \\
\text { Appropriate Workload, Emphasis on Independence }\end{array}$ \\
\hline
\end{tabular}

* The attributes in bold italicized font are related to self-directedness. 
of pedagogy, perception of technology, perceived usefulness to career, selected learning methods, and perceived emphasis on independence. These reflect the effective principles when developing an online outreach education program for adult audiences in the Holland study, which provides sufficient interaction opportunities that support knowledge construction and learner empowerment (Holland, 2019).

The lack of an intact instrument measuring self-directedness in MOOC design could be the derivatives of the disjoint between instructional design and the actual teaching of MOOCs, as discovered by Czerkawski (2016) in his review and synthesis of empirical research on networked learning for online higher education courses. Czerkawski found that few instructional designers and their perspectives were included when designing a networked online learning environment. Moreover, Czerkawski (2016) added that larger-scale and longitudinal quantitative studies could offer new insights.

Therefore, an instrument measuring design features that scaffold self-determined and selfdirected learning is needed. The constructs ought to focus primarily on online MOOCs, self-directed learning, and considering the adult audience as the primary stakeholders. Such an instrument can help inform the design of MOOCs by understanding learners' perceptions of design variables that allow learner choices. Therefore, this study is purposed to develop this instrument based on the literature review, and conduct the initial analysis of factor structure, validity, and reliability in a real MOOC environment.

\section{Design Variables}

Based on the literature review, a 3-construct 21-item Massive Online Open
Course Learning Environment Design Questionnaire (MOOC-LED) was developed. The core constructs of this instrument surround learner-centeredness. Three design variables are measured in a complete learning cycle that learners experience, including learning material presentation, interaction, and outcome assessment. These variables are derived by following the heutagogical design process (Blaschke \& Hase, 2015). They are mapped to the three primary components including learner-defined learning contracts, learning activities, and learning outcomes. For example, learning activities are viewed as a series of interactions with either the system, peers, or the teacher. These three design variables are described from a learner-centered view as follows.

For the learning material presentation variable, learning materials ought to be organized in a way that learners can easily choose for navigation (V1). When learning material presentations are equipped with a tracking function, learners can find the last learning location (V2) as they choose to. Besides, learning materials ought to be segmented to several parts (e.g. quiz or discussion) according to their difficulties, so that learners can select the content (V6) appropriate to their levels. These three items are designed to underpin "learnerdefined learning contracts". Besides these items on the format, three items on content are mapped under the construct of learning material presentation. The first one is that the requirement or rule is simple (V5), which is designed to support a "flexible curriculum". The second one is that the course preview is enjoyable and appealing (V3), and the third one is that the lecture video is elaborately designed (V4).

For the interaction variable, there are three kinds of interactions, including system-learner, learner-learner, and learner- 
teacher interactions. For the system-learner interaction, pre-tests are used to understand learners' characteristics for the content recommendation (V7). And layered resources are provided for learners with different competencies (V8). These two items are designed to enhance "learner-defined learning contracts". In addition, the feedback from the system ought to be on time (V11).

For the learner-learner interaction, peers are usually assigned to collaborate with a learner according to her status (V12). And the learners are expected to accomplish tasks with peers (V16). These two items are designed to enable "team-based" collaborative learning. For the effectiveness of collaborative learning, peer discussions are used to help to solve problems (V15), and collaborative discussion is anticipated to deepen understanding (V17). The former item focuses on "knowledge sharing", while the latter one focuses on reflective practice by using "learning journals". Discussions in MOOCs can be regarded as a special kind of learning journals since they are usually carried out by written text, and usually concentrated on the interesting or valuable learned content or scenarios.

For the learner-teacher interaction, the learning procedure consists of 4 phases, including learning, mastering, applying, and trying (V9). This is similar to "action research" for teaching improvement (Feldman \& Minstrell, 2000; Gilles, Wilson, \& Elias, 2010). Through the systematic observations and study of these action research, learning is analyzed as a series of steps where environment, system, or practice may be changed gradually. An observer (e.g., teacher) usually researches the learner's actions in such a continuingly changing environment and advises the learner. Action research allows experimentation with real-world experience where learning is in the hands of the participants. The learning can then be tested in subsequent learning cycles (Hase \& Kenyon, 2007). Besides V9, learner-teacher interaction also occurs in V10, proportions of videos, tests, and discussions are designed with the consideration of learners' needs. V10 emphasizes a flexible curriculum, otherwise, the single format may make learning activities rigid and not easily determined by learners. The questions from learners ought to be answered on time by teachers or teaching assistants (V14). This item echoes "learnerdirected questions". Also, learners should have choices of participation in the discussion actively and positively (V13).

For the outcome assessment variable, the peer assessment or posting behavior ought to be rewarded, e.g., credits (V19). This item is connected to "formative assessment" since either peer assessment or posting is a positive learning behavior during knowledge or skill formation. These behaviors deserve a positive assessment, i.e., rewards so that learners can be encouraged to accelerate knowledge or skill formation. The learners also are provided with a summative assessment after they accomplish a mission (V20). This item is linked to "summative assessment". Inspired by "flexible \& negotiated assessment"(Blaschke, 2012), as item V21 is proposed, that is, the final credits can be traded for offline gifts, including the opportunity for joining MOOC teachers' other activities, such as research-related informal seminars or book clubs. To achieve these goals, the system ought to tell learners how to earn extra credits first (V18). This item comes from "learner-centeredness".

The mapping between the MOOC-LED design variables, items, and heutagogical attributes are presented in Table 3 .

\section{Study of MOOC-LED Structure, Validity,} and Internal Reliability 
Table 3. Design Variables, Items, and Heutagogical Elements in MOOC-LED

\begin{tabular}{|c|c|c|c|}
\hline $\begin{array}{c}\text { Design } \\
\text { Variable }\end{array}$ & Item & attributes/statements & heutagogical perspective \\
\hline \multirow{6}{*}{$\begin{array}{l}\text { learning } \\
\text { material } \\
\text { presentation }\end{array}$} & $\mathrm{V} 1$ & $\begin{array}{l}\text { The navigation bar helps to locate } \\
\text { resources. }\end{array}$ & $\begin{array}{l}\text { learner-defined learning } \\
\text { contracts }\end{array}$ \\
\hline & $\mathrm{V} 2$ & $\begin{array}{l}\text { Learning is tracked. It is convenient to find } \\
\text { the exact place to resume. }\end{array}$ & $\begin{array}{l}\text { learner-defined learning } \\
\text { contracts }\end{array}$ \\
\hline & V3 & $\begin{array}{l}\text { The course preview is enjoyable and } \\
\text { appealing. }\end{array}$ & learner-centeredness \\
\hline & V4 & The lecture video is elaborately designed. & learner-centeredness \\
\hline & V5 & The requirement or rule is simple. & flexible curriculum \\
\hline & V6 & $\begin{array}{l}\text { Learning material is segmented into } \\
\text { several parts (e.g., quiz, discussion) by } \\
\text { difficulties. }\end{array}$ & $\begin{array}{l}\text { learner-defined learning } \\
\text { contracts }\end{array}$ \\
\hline \multirow{11}{*}{ interaction } & V7 & $\begin{array}{l}\text { Pre-tests are used to understand } \\
\text { learners' characteristics for content } \\
\text { recommendation. }\end{array}$ & $\begin{array}{l}\text { learner-defined learning } \\
\text { contracts }\end{array}$ \\
\hline & V8 & $\begin{array}{l}\text { Resources are layered for learners with } \\
\text { different competencies. }\end{array}$ & $\begin{array}{l}\text { learner-defined learning } \\
\text { contracts }\end{array}$ \\
\hline & V9 & $\begin{array}{l}\text { Learning procedure consists of } 4 \text { phases: } \\
\text { learning, mastering, applying and trying. }\end{array}$ & action research \\
\hline & V10 & $\begin{array}{l}\text { The proportions among videos, tests, and } \\
\text { discussions are proper. }\end{array}$ & flexible curriculum \\
\hline & V11 & The feedback from the system is on time. & learner-centeredness \\
\hline & V12 & $\begin{array}{l}\text { The system may assign peers to cooperate } \\
\text { with a learner according to her status. }\end{array}$ & $\begin{array}{l}\text { team-based learning } \\
\text { (at learner choice) }\end{array}$ \\
\hline & V13 & $\begin{array}{l}\text { Learners are led to participate in the } \\
\text { discussion actively and positively. }\end{array}$ & learner-centeredness \\
\hline & V14 & $\begin{array}{l}\text { The questions from learners are answered } \\
\text { on time by teachers or teaching assistants. }\end{array}$ & $\begin{array}{l}\text { learner-directed } \\
\text { questions }\end{array}$ \\
\hline & V15 & Peer discussions help to solve problems. & knowledge share \\
\hline & V16 & The learners accomplish tasks with peers. & $\begin{array}{l}\text { team-based learning (at } \\
\text { learner choice) }\end{array}$ \\
\hline & V17 & The discussion deepens understanding. & learning journals \\
\hline \multirow{4}{*}{$\begin{array}{l}\text { outcome } \\
\text { assessment }\end{array}$} & V18 & $\begin{array}{l}\text { The system tells learners to earn extra } \\
\text { credits. }\end{array}$ & learner-centeredness \\
\hline & V19 & $\begin{array}{l}\text { The peer assessment or posting behavior is } \\
\text { rewarded, e.g., credits. }\end{array}$ & formative assessment \\
\hline & V20 & $\begin{array}{l}\text { The learner is rewarded on time for } \\
\text { mission accomplished, such as badges. }\end{array}$ & summative assessment \\
\hline & V21 & $\begin{array}{l}\text { The final credits of learners can be traded } \\
\text { for gifts offline }\end{array}$ & $\begin{array}{l}\text { flexible \& negotiated } \\
\text { assessment }\end{array}$ \\
\hline
\end{tabular}




\subsection{Methods and Context}

The study used a survey design to test the initial structure, validity, and internal reliability of the MOOC-LED questionnaire after its development (Creswell \& Creswell, 2018). The 21 items were written based on the literature review and MOOC design and teaching experiences of faculty members. The instrument was then reviewed by experts in learning psychology, and those having expertise in the design and teaching with MOOCs environments to establish its initial face validity. The instrument was also reviewed by potential learners in MOOCs to test its readability (DeVellis, 2012). The 3-construct, 21-item MOOCLED presented in Table 3 was used to assess students' perceptions of a real-world MOOC learning environment with some intentionally integrated learning choice features (Figure 1). The prompt question in the questionnaire was: how important is this statement for your

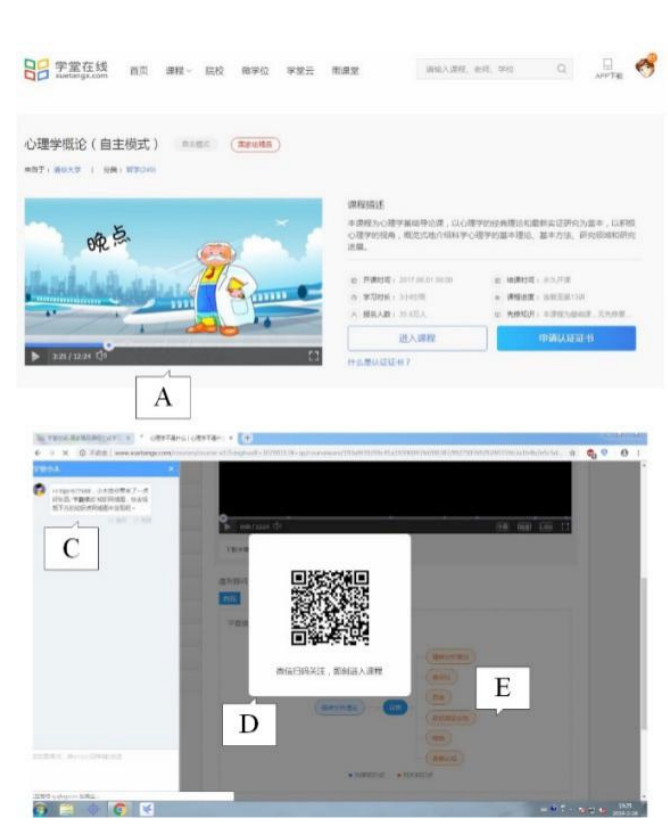

A. Using an illustrative animation in the preview.

B. Popping up a question from a student on the screen in real time.

C. Reminding students by an artificial intelligent learning assistant to pay attention to $\mathrm{E}$ area (knowledge graph).

D. Showing a QR code for students to scan and join a group chat with cell phones, setting up social connections.

E. Presenting a structured knowledge graph.

Figure 1. Samples of Design Elements in a MOOC Platform (xuetangx.com) 
D shows a further choice that invites learners to join a social group, which may facilitate more off-line learning activities. Subfigure E shows a structured knowledge graph, helping learners recognize her current learning status for a better decision on future learning paths.

\subsection{Participants}

This cross-section survey research recruited 162 Chinese graduate students as anonymous samples. They were in the first year in their Educational Technology graduate program. Although they were enrolled in one normal university in central China, their native places and undergraduate majors varied. The demographic representation of these students was $27.16 \%$ of natives from Shan Dong Province, $22.22 \%$ of natives from $\mathrm{Hu}$ Bei Province, and $19.75 \%$ of natives from $\mathrm{Si}$ Chuan Province, representing northeastern, central, and southwestern regions in China respectively and making up $69.13 \%$ survey participants. The rest of the participants came from other areas of China. These students also majored in diverse disciplines of study. Their majors covered education (44.44\%),

Table 4. Item Factor Analysis Results

\begin{tabular}{|c|c|c|c|}
\hline \multirow[b]{2}{*}{ Item No. } & \multicolumn{3}{|c|}{ Rotated Factor Loadings (values larger than 0.4 are shown) } \\
\hline & $\begin{array}{c}\text { learning material } \\
\text { presentation }\end{array}$ & interaction & outcome assessment \\
\hline V1 & .681 & & \\
\hline $\mathrm{V} 2$ & .746 & & \\
\hline V3 & .475 & & \\
\hline V4 & .657 & & \\
\hline V5 & .728 & & \\
\hline V6 & .682 & & \\
\hline V7 & & .548 & \\
\hline V8 & & .664 & \\
\hline V9 & & .547 & \\
\hline V10 & & .583 & \\
\hline V11 & & .472 & \\
\hline V12 & & .744 & \\
\hline V13 & & .613 & \\
\hline V14 & & .615 & \\
\hline V15 & & .721 & \\
\hline V16 & & .711 & \\
\hline V17 & & .793 & \\
\hline V18 & & & .783 \\
\hline V19 & & & .647 \\
\hline V20 & & & .705 \\
\hline V21 & & & .750 \\
\hline$\%$ of variance & 26.65 & 25.23 & 17.00 \\
\hline $\begin{array}{c}\text { Cumulative } \% \\
\text { of variance }\end{array}$ & 26.65 & 51.88 & 68.88 \\
\hline
\end{tabular}


information science $(22.22 \%)$, philosophy $(22.22 \%)$, and engineering $(11.12 \%)$. The gender distribution was $60.49 \%$ female and $39.51 \%$ male. They were 24.7 years old on average.

\subsection{Data Analysis Results}

SPSS 25 and AMOS 20.0 were used to conduct an initial analysis of the MOOCLED instrument structure and validity. With Eigenvalue $>1$, three factors accounted for the magnitude of $68.88 \%$ of the total variance. Among them, 6 items loaded on Factor 1 with focus on learning materials presentation, accounted for $26.65 \%$ of the variance; 11 items loaded on Factor 2 with focus on interaction, accounted for $25.23 \%$ of the variance, and 4 items loaded on Factor 3 with focus on outcome assessment, accounted for $17.00 \%$ of the variance (Table 4 ).
A confirmatory factor analysis (CFA) was performed to initially examine the factor validity of MOOC-LED. According to Marsh, Balla, and McDonald (1988), and MacCallum, Widaman, Zhang, and Hong (1999), $\chi 2 / d f$, the Non-Normed Fit Index (NNFI), the Comparative Fit Index (CFI) and the Root Mean Square Error of Approximation (RMSEA) were used to indicate the robustness of fit in CFA. If $\chi^{2} / \mathrm{df}$ is less than 3 , NNFI and CFI are both above 0.95 , and RMSEA is less than 0.06, they indicate an acceptable data fit (Schreiber, Stage, King, Nora \& Barlow, 2006).

The goodness-of-fit indices were $\chi 2 /$ $\mathrm{df}=1.53, \mathrm{NNFI}=0.952, \mathrm{CFI}=0.962$, and RMSEA $=0.057$. They indicated that the 3-construct, 21 items MOOC-LED had an acceptable fit with the current sample, no further model modification needed. In Figure 2, the CFA visual results showed that all items

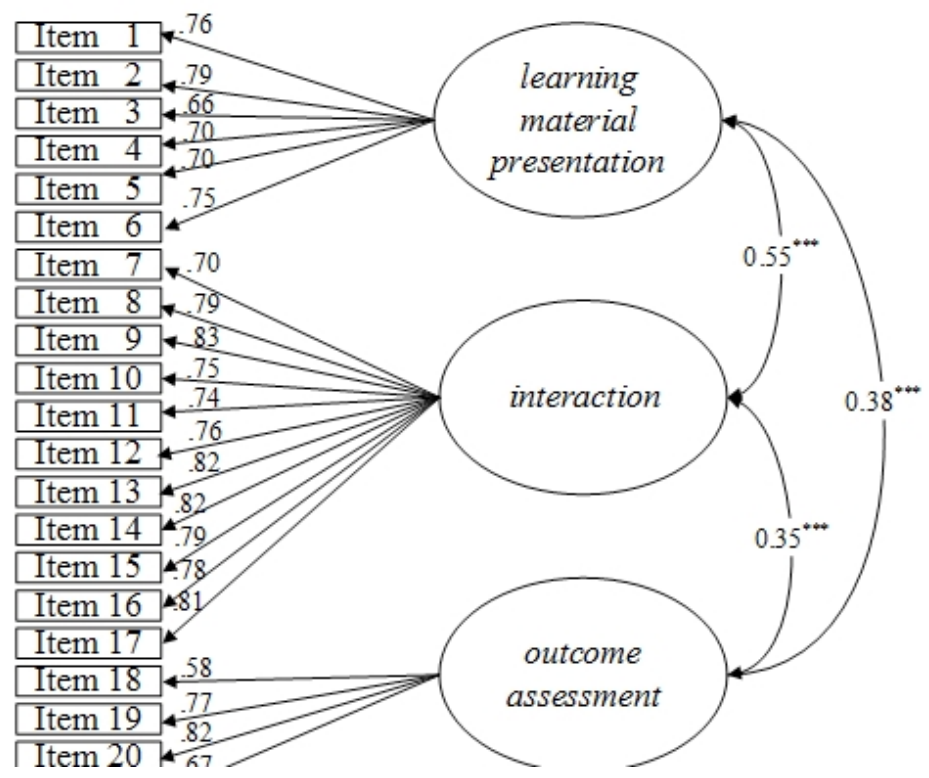

Figure 2. CFA Results of MOOC-LED $(\mathrm{n}=162),{ }^{* * *}$ : $\mathrm{p}<0.001$ 
had moderate to high factor loading values, ranging from .58 to .83 .

The results also indicated that Cronbach's $\alpha$ coefficients of all three subscales, Learning Material Presentation, Interaction, and Outcome Assessment were 0.88, 0.94, and 0.80 at the significant level of 0.001 . The Cronbach alpha of 21 items was 0.96 . These were all above .80 , indicating the MOOC-LED had satisfactory internal consistency with the sample of this study.

\section{Discussion}

\subsection{On the MOOC-LED Factor Structure, Validity, and Internal Reliability}

The study results provided answers to the two research questions. To answer the $R Q$ 1 - What are the design variables for selfdirected learning in a MOOC environment? the 3-construct 21 items of MOOC-LED was developed based on a literature review about online course design, self-directed learning, and online learning instruments as well as the expertise and experiences in the design and teaching with MOOC environments. The cross-section survey data collected from 162 learners' perceptions in a real MOOC environment were analyzed. The results indicated that the three constructs of learning material presentation, interaction, and outcome assessment formed an inter-related cycle to support learner-centered teaching and learning process. Collectively, these design variables mapped with the three elements in heutagogical design process, that is, learnerdefined learning contracts, learning activities, and learning assessment.

To answer the $R Q 2$ - How reliable and valid are these design variables as an instrument to inform MOOC design? Quantitative analyses of factor structure, validity, and internal reliability were conducted. For all three constructs, the Cronbach alpha coefficients were above .80 , with learning material presentation $\alpha=.88$, interaction $\alpha=.94$, and outcome assessment $\alpha=80$. The Cronbach's alpha of the entire instrument of 21 items was 0.96 .

The item factor analysis and CFA results indicated that the 21 items loaded to three constructs and that there was an acceptable fit of the factor structure of the MOOCLED. These results meant that the instrument measured what it was claimed to measure the design variables in a MOOC environment.

\subsection{Implications}

The implications for MOOC practitioners are presented in two aspects. In developed countries, MOOC has evolved into a postMOOC stage, where it is gradually integrated into business models (Daniel, Vázquez Cano, \& Gisbert, 2015). In such models, MOOC is inevitably treated as services or products (Porter, 2015), where learners can be regarded as knowledge consumers or buyers. Also, they are often middle-aged adults. Therefore, learner choices and learner-centeredness should also be valued in MOOC design, as they are placed in a central position in other commercial circumstances. Giving learners more choices to harness their learning is an effective strategy.

In developing countries, MOOC stays at its original stage as a platform to deliver educational content. Nordin, Norman, and Hamdan (2018) support that MOOC is an effective technology platform to achieve this Sustainable Development Goal 4 (SDG 4) in 2030 Agenda of United Nations Educational Scientific and Cultural Organization (UNESCO). Empowering more autonomy to learners will improve their experiences or perceptions of learning, which will be alternative or complementary for their in- 
classroom learning.

\subsection{Limitations}

The limitation is that the learner-perceived design variables and their relationships may differ slightly among different countries because of their ages when taking MOOCs, e.g., major Chinese and American MOOC students. This study has had a sample of limited age range.

According to Oudeweetering and Agirdag (2018)'s investigation, the average age of American MOOC learners is above 34. Li (2017) also has found through a survey of 32 MOOCs with 11,933 United States respondents, only $23.5 \%$ of US MOOC students are under 30 . However, these findings are not always coherent. For example, Glass, Shiokawa-Baklan, and Saltarelli (2016) have summarized that the median age of a typical MOOC student is younger than 30 , or nearly two of three MOOC students are younger than 35. Guo and Reinecke (2014) found that the mean student age across some four courses was 28 years. While Dillahunt, Wang, and Teasley (2014) found that the largest age group taking MOOCs was those of 25-34 years old $(39.78 \%)$, and the second one was those between $18-24$ years old $(22.67 \%)$.

Different from American datasets, Chinese MOOC participants exhibit a different pattern in learners' average ages. MOOC learners in China are younger. Based on a report on 30,187 Chinese MOOC students, $69.32 \%$ of them are in the age group of 17-26 years old (Li, 2017). Though Chinese MOOC students are younger than US students, the same survey addresses that the percentage of working professionals in MOOCs in China is increasing every year (Li, 2017). Li (2017) also found that in $51.5 \%$ of Chinese MOOC students state that they take MOOCs to advance their professional skills. These students are making investment with their time to study materials that they believe will help them on their future career path.

Therefore, though Chinese and American MOOC students have different average ages, they are either working professionals or to be working professionals. The majority of either Chinese or American students actually both take MOOCs as a form of after-college education. Comparing to teenagers, young or middle-aged adults are more willing and also able to conducted self-determined learning. This verifies the purpose of this study to investigate the design variables of selfdirected MOOC learning environment from a heutagogical perspective. The influences of different ages on the design factor structure and the relationships among design variables can be studied in the future.

Another limitation is related to the current technical environment of MOOCs. Most MOOCs can only offer two or three final academic achievement levels, that is, failed, passed or excellent. It would be much better to improve learner autonomy if MOOCs can be segmented into smaller chunks so that a specific unit of knowledge or skill that learners are interested can be assessed separately. And these small pieces may also meet the needs of learning contracts defined by learners.

\section{Conclusion}

Currently, an ordinary MOOC is often designed in traditional pedagogy. It is usually well-packaged from instructors' perspectives, not learner-centered orientations. This paradigm will not be inclusive enough for those who are willing to determine their learning, especially for those who are already young and middle-aged adults. Following a heutagogy and self-directed conceptual framework, a 3-construct, 21-item MOOCLED questionnaire has been developed in 
the study. The three design constructs are learning material presentation, interaction, and outcome assessment. Collectively, they elaborate on three learner-choice elements of heutagogical design, including learnercenteredness, reflective practice, and collaborative learning. These three design variables have been initially validated through a survey deployed to and responded by 162 graduate students taking MOOCs in China. The research results have unveiled that if a MOOC learning environment values more learning choices, learners would be more active in such an environment. More studies on self-directedness of the MOOC learning environment, for instance, with different ages and social economic status, are expected in the future.

\section{Acknowledgement}

The authors would like to extend their thanks to the sponsorship from Natural Science Foundation of China (No. 31600918) on the research project. The detailed and constructive feedback from the journal reviewers are very much appreciated.

\section{References}

Agonács, N., \& Matos, J. F. (2017a). Engagement driven massive and open online learning environment: A heutagogy-based MOOC (h-mooc). In European Conference on e-Learning (pp. 537-545). Academic Conferences International Limited.

Agonács, N., \& Matos, J.F. (2017b). Towards a heutagogy-based mooc design framework, Proceedings of EMOOCs 2017: work in process papers of the experience and research tracks and position paper of the policy track, 47-52.

Aldridge, J.M., Dorman, J.P., \& Fraser, B. J. (2004). Use of multitrait-multimethod modelling to validate actual and preferred forms of the technology-rich outcomesfocused learning environment inventory (troflei). Australian Journal of Educational \& Development Psychology, 4, 110-125.

Anders, A. (2015). Theories and applications of massive online open courses (MOOCs): The case for hybrid design. International Review of Research in Open and Distributed Learning, 16(6), 39-61. doi: 10.19173/irrodl.v16i6.2185

Bonk, C. J., Zhu, M., Kim, M., Xu, S., Sabir, N., \& Sari, A. R. (2018). Pushing toward a more personalized MOOC: Exploring instructor selected activities, resources, and technologies for MOOC design and implementation. International Review of Research in Open and Distributed Learning, 19(4). doi: 10.19173/irrodl. v19i4.3439

Argyris, C., \& Schon, D. A. (1978) Organizational Learning: A theory of action perspective. Reading, MA: Addison Wesley.

Blaschke, L. M. (2018). Self-determined learning (heutagogy) and digital media creating integrated educational environments for developing lifelong 
learning skills. In D. Kergel, B. Heidkamp, P. K. Telléus, T. Rachwal, \& S.1 Nowakowski (Eds.), The Digital Turn in Higher Education (pp. 129-140). Springer VS, Wiesbaden.

Blaschke, L.M., \& Hase, S. (2015). Heutagogy: A holistic framework for creating twenty-first-century selfdetermined learners. In B. Gros et al. (eds.), The future of ubiquitous learning, Lecture Notes in Educational Technology (pp. 25-40), doi: 10.1007/978-3-66247724-3 2

Blaschke, L.M. (2012). Heutagogy and lifelong learning: A review of heutagogical practice and self-determined learning. The International Review of Research in Open and Distance Learning, 13(1), 56-71. doi: 10.19173/irrodl.v13i1.1076

Bonk, C. J., Lee, M. M., Reeves, T. C., \& Reynolds, T. H. (Eds.). (2015). MOOCs and open education around the world. New York, NY: Routledge.

Chang, V., \& Fisher, D. (2003). The validation and application of a new learning environment instrument for online learning in higher education. TechnologyRich Learning Environments: A Future Perspective, 1-20, World Scientific Publishing Co. Pte. Ltd.

Creswell, J. W., \& Creswell, J. D. (2018). Research Design: Qualitative, Quantitative, and Mixed Methods Approaches (5th ed.). Thousand Oaks, CA: Sage Publications.

Czerkawski, B. C. (2016). Networked learning: design considerations for online instructors. Interactive Learning Environments, 24(8), 1850-1863. doi: $10.1080 / 10494820.2015 .1057744$.

Daniel J., Vázquez Cano E., \& Gisbert, M. (2015). The future of MOOCs: adaptive learning or business Model? RUSC. Universities and Knowledge Society Journal, 12(1), 64-73. doi: 10.7238/rusc. v12i1.2475
DeVellis, R.F. (2012). Scale development: Theory and applications (3rd ed.). Thousand Oaks, CA: SAGE Publications.

Dillahunt, T., Wang, Z., \& Teasley, S. (2014). Democratizing higher education: exploring MOOC use among those who cannot afford a formal education, The International Review of Research in Open and Distributed Learning, 15(5). doi: 10.19173/irrodl.v15i5.1841

Feldman, A., \& Minstrell, J. (2000). Action research as a research methodology for the study of the teaching and learning of science. ERIC Clearinghouse.

Fernandez, M. R., Silvera, J. L. S., \& Meneses, E. L. (2015). Comparative between quality assessment tools for moocs: adecur vs standard une 66181: 2012, RUSC Universities and Knowledge Society Journal, 12 (1), 131-144. doi: 10.7238/rusc.v12i1.2258

Garrison, D.R., Anderson, T., \& Archer, W. (1999). Critical inquiry in a text-based environment: Computer conferencing in higher education. The Internet and Higher Education, 2(2-3), 87-105. doi: 10.1016/ S1096-7516(00)00016-6

Garrison, D. R. (1997). Self-directed learning: Toward a comprehensive model. Adult education quarterly, 48(1), 18-33.

Gilles, C., Wilson, J., \& Elias, M. (2010). Sustaining teachers' growth and renewal through action research, induction programs, and collaboration. Teacher Education Quarterly, 37(1), 91-108.

Glass, C. R., Shiokawa-Baklan, M. S., \& Saltarelli, A. J. (2016). Who takes MOOCs? New Directions for Institutional Research, 2015(167): 41-55. doi: 10.1002/ ir.20153

Grabowski, B. L., \& Curtis, R. (1991). Information, instruction and learning: A hypermedia perspective. Performance Improvement Quarterly, 4(3), 2-12. doi: 10.1111/j.1937-8327.1991.tb00510.x

Gregory, S., Bannister-Tyrrell, M., Charteris, 
J., \& Nye, A. (2018). Heutagogy in postgraduate education: Cognitive advantages for higher degree online students. In R. Erwee et al. (eds.), Postgraduate Education in Higher Education, University Development and Administration (pp. 189-209), doi: 10.1007/978-981-10-5249-1_32

Guo, P. J., \& Reinecke, K. (2014). Demographic differences in how students navigate through MOOCs, In M. Sahami (Ed.), Proceedings of Learning at Scale L@S (pp.21-30), Atlanta, Georgia, USA: ACM. doi: $10.1145 / 2556325.2566247$

Handoko, E., Gronseth, S. L., McNeil, S. G., Bonk, C. J., \& Robin, B. R. (2019). Goal setting and mooc completion: A study on the role of self-regulated learning in student performance in massive open online courses. The International Review of Research in Open and Distributed Learning, 20(3). doi: 10.19173/irrodl.v20i4.4270

Hansen, J. D., \& Reich, J. (2015, March). Socioeconomic status and MOOC enrollment: enriching demographic information with external datasets. In Proceedings of the Fifth International Conference on Learning Analytics and Knowledge (pp. 59-63). ACM.

Hase, S. (2009). Heutagogy and e-learning in the workplace: some challenges and opportunities. Impact: Journal of Applied Research in Workplace E-learning, 1(1), 43-52. doi: 10.5043/ impact. 13

Hase, S., \& Kenyon, C. (2007). Heutagogy: A child of complexity theory. Complicity: An International Journal of Complexity and Education, 4(1): 111118. doi: $10.29173 /$ cmplct 8766

Holland, A. A. (2019). Effective principles of informal online learning design: A theory-building meta synthesis of qualitative research. Computers \&
Education, 128, 214-226. doi: 10.1016/ j.compedu.2018.09.026

Jaggars, S.S., \& Xu, D. (2016). How do online course design features influence student performance? Computers \& Education, 95, 270-284. doi: 10.1016/ j.compedu.2016.01.014

Li, Y. (2017). Massive open online courses (moocs) in the United States, China and India. In C. Huang, Y. Zhong, \& Z. Wang (Eds.), Proceedings of 2nd International Conference on Modern Management, Education Technology, and Social Science, Singpore: Atlantis Press.

Liu, J. C., John, K. S., \& Bishop Courtier, A. M. (2017). Development and validation of an assessment instrument for course experience in a general education integrated science course, Journal of Geoscience Education, 65, 435-454. doi: 10.5408/16-204.1

MacCallum, R. C., Widaman, K. F., Zhang, S., \& Hong, S. (1999). Sample size in factor analysis. Psychological Methods, 4(1), 84-99. doi: 10.1037/1082-989X.4.1.84

Margaryan, A., Bianco, M., \& Littlejohn, A. (2015). Instructional quality of massive open online courses (moocs). Computers \& Education, 80, 77-83. doi: 10.1016/ j.compedu.2014.08.005

Marsh, H. W., Balla, J. R., \& McDonald, R. P. (1988). Goodness-of-fit indexes in confirmatory factor analysis: the effect of sample size. Psychological Bulletin, 103(3), 391-410. doi: 10.1037/00332909.103.3.391

Merrill, D.M. (2002). First principles of instruction. Educational Technology Research \& Development, 50(3), 43-59. doi: 10.1007/BF02505024

Moore, M.G. (1991). Editorial: Distance education theory. American Journal of Distance Education, 5(3), 1-6. doi: $10.1080 / 08923649109526758$

Moore, M.G. (1973). Toward a theory of independent learning and teaching. The 
Journal of high education, 44(9), 661-679. doi: $10.1080 / 00221546.1973 .11776906$

Nordin, N., Norman, H., \& Hamdan, F. (2018). Quality education with instructional design via massive open online courses. Advanced Science Letters, 24(4), 25412545. doi: 10.1166/asl.2018.11000

Ogbuehi, P. I., \& Fraser, B. J. (2007). Learning environment, attitudes and conceptual development associated with innovative strategies in middle-school mathematics, Learning Environment Research, 10, 101114. doi: 10.1007/s10984-007-9026-Z

Oudeweetering, K., \& Agirdag, O. (2018). Demographic data of MOOC learners: Can alternative survey deliveries improve current understandings? Computers \& Education, 122, 169-178. doi: 10.1016/ j.compedu.2018.03.017

Porter, S. (2015). Understanding your market: the learner as consumer. In S. Porter (Ed.) To MOOC or not to MOOC- How can online learning help to build the future of higher education? (pp. 107-114). Walham, MA: Chandos Publishing. doi: 10.1016/ B978-0-08-100048-9.00016-0

Pursel, B. K., Zhang, L., Jablokow, K. W., Choi, G. W., \& Velegol, D. (2016). Understanding MOOC students: motivations and behaviours indicative of MOOC completion. Journal of Computer Assisted Learning, 32(3), 202-217.

Reker, G. T. (2005). Meaning in life of young, middle-aged, and older adults: factorial validity, age, and gender invariance of the personal meaning index (PMI). Personality and Individual Differences, 2005, 38(1), 71-85. doi: 10.1016/j.paid.2004.03.010

Rovai, A. P. (2002). Development of an instrument to measure classroom community. Internet and High Education, 5, 197-211. doi: 10.1016/s 1096 7516(02)00102-1

Schreiber, J.B., Stage, F.K., King, J., Nora, A., \& Barlow, E.A. (2006). Reporting structural equation modeling and confirmatory factor analysis results: A review. Journal of Educational Research, 99, 323-337. doi: 10.3200/JOER.99.6.323338

Shapiro, H. B., Lee, C. H., Roth, N. E. W., Li, K., Çetinkaya-Rundel, M., \& Canelas, D. A. (2017). Understanding the massive open online course (MOOC) student experience: An examination of attitudes, motivations, and barriers. Computers \& Education, 110, 35-50. doi: 10.1016/ j.compedu.2017.03.003

Tagg, J. (2010). The learning-paradigm campus: From single- to double-loop learning. New Directions for Teaching and Learning, 2010(123), 51-61. doi:10.1002/ tl. 409

Thomas, G. P. (2003). Conceptualisation, development and validation of an instrument for investigating the metacognitive orientation of science classroom learning environments: the metacognitive orientation learning environment scale - science (Moles-S). Learning Environment Research, 6, 175197. doi: 10.1023/A:1024943103341

Walker, S. L., \& Fraser, B. J. (2005). Development and validation of an instrument for assessing distance education learning environments in higher education: the distance education learning environments survey (deles). Learning Environment Research, 8, 289-308. doi: 10.1007/s10984-005-1568-3

Wu, J.H., Tennyson, R. D., \& Hsia, T. L. (2010). A study of student satisfaction in a blended e-learning system environment, Computers \& Education, 55, 155-164. doi: 10.1016/j.compedu.2009.12.012

Yousef, A. M. F., Chatti, M. A., Schroeder, U., \& Wosnitza, M. (2014). What drives a successful mooc? An empirical examination of criteria to assure design quality of moocs. In: D.G. Sampson, J.M. Spector, N.S. Chen, R. Huang, \& Kinshuk (Eds.). Proceedings of IEEE International 
Conference on Advanced Learning Technologies (pp.44-48). Greece: IEEE. doi: 10.1109/ICALT.2014.23

\section{Contact the Author}

Tai Wang

Central China Normal University

Email:wangtai@mail.ccnu.edu.cn

Juhong Christie Liu

James Madison University

Email: liujc@jmu.edu

Tonggui Li

Peking University

Email: litg@pku.edu.cn 